\title{
Uranium content in rivers of the Narssaq area, South Greenland
}

\section{Gert Asmund}

The use of small bags filled with ion exchange resin placed in running water (Asmund, 1974) has proved to be a most useful method for investigation of the distribution of dissolved $\mathrm{Zn}, \mathrm{Cd}, \mathrm{Pb}, \mathrm{Cu}, \mathrm{Cr}, \mathrm{Ni}$ and $\mathrm{U}$ in fresh water streams in a $2000 \mathrm{~km}^{2}$ area around Narssaq, South Greenland.

\section{Methods}

The geochemical method employed appears to be particularly well suited to the detection of uranium. Of the two ion exchangers in use, type 1 concentrates uranium 19700 times, which means that water with $1 \mathrm{ppb}$ uranium yields an ion exchanger with $19.7 \mathrm{ppm}$ uranium, while ion exchanger type 2 has a concentration factor of 32900 . These values have been determined at the Danish Atomic Energy Commission's Research Establishment, Ris $\phi$, by adding $10 \mu \mathrm{g}$ of $\mathrm{U}^{233}$ to 401 of water and bringing the ion exchanger into contact with the water until equilibrium was reached. The proportion of $U^{233}$ taken up by the ion exchanger was then determined by mass spectrometry.

Table 3. Uranium content of fresh water in the Narssaq river basin

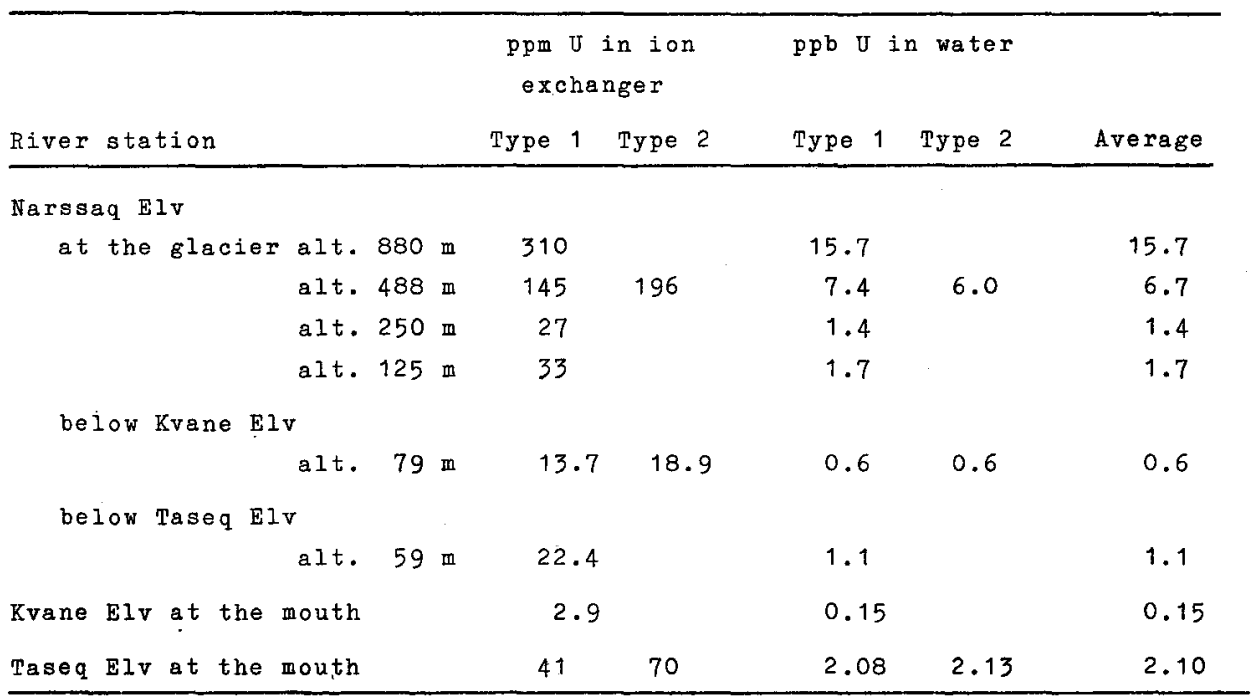




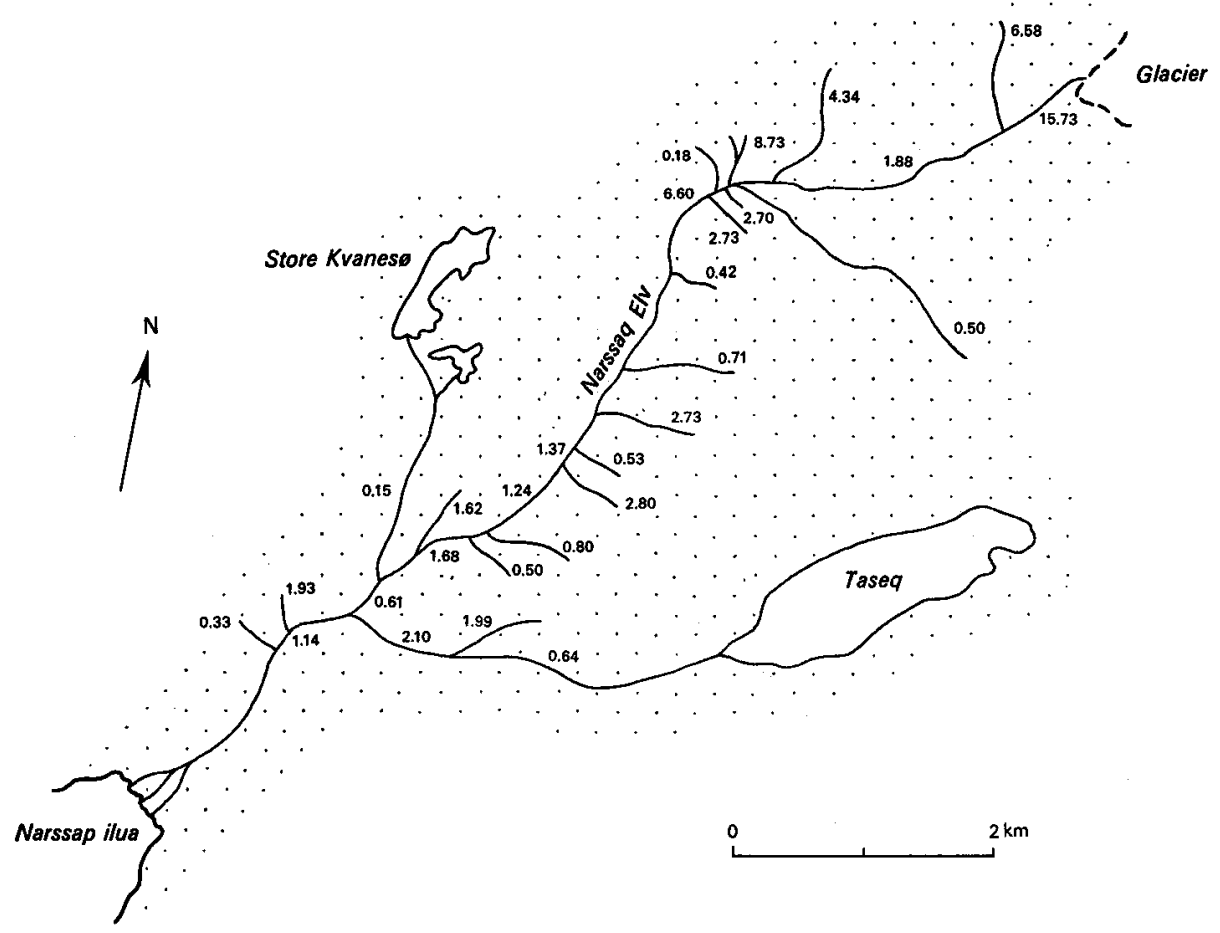

Fig. 17. Distribution of uranium (ppb) in the Narssaq river basin.

\section{Results from the Narssaq river basin}

The hydrology and hydrochemistry of the Narssaq River Basin have been investigated since 1965 (Larsen, 1973) and a uranium deposit at Kvanefjeld is located inside the basin. This deposit is drained by Kvane Elv which joins Narssaq Elv at an altitude of $80 \mathrm{~m}$ after having passed Store Kvanes $\varnothing$. At an altitude of $60 \mathrm{~m}$ Taseq Elv joins Narssaq Elv (fig. 17).

The two first columns in Table 3 give the content of uranium in the type 1 and 2 ion exchangers after equilibrium with the stream water has been reached. These have been analysed by the delayed neutron method at Ris $\varnothing$. In columns 3 and 4 these numbers have been divided by the concentration factors, mentioned above, giving the calculated concentration of dissolved uranium in the water. The corresponding numbers in columns 3 and 4 should be equal, the relatively small difference reflects the accuracy of the method.

It is surprising to see that the uranium concentration is highest $(15.7 \mathrm{ppb})$ near the glacier, which is at a higher elevation than the known uranium deposit at Kvanefjeld. However, high surface radioactivity has recently been found in the same area (Sørensen, in press). The concentration of uranium decreases as the river descends through the valley, probably due to absorption in organic material. Kvane Elv, having passed Store Kvanes $\varnothing$ which is rich in vegetation, is nearly free of uranium $(0.15 \mathrm{ppb})$ 


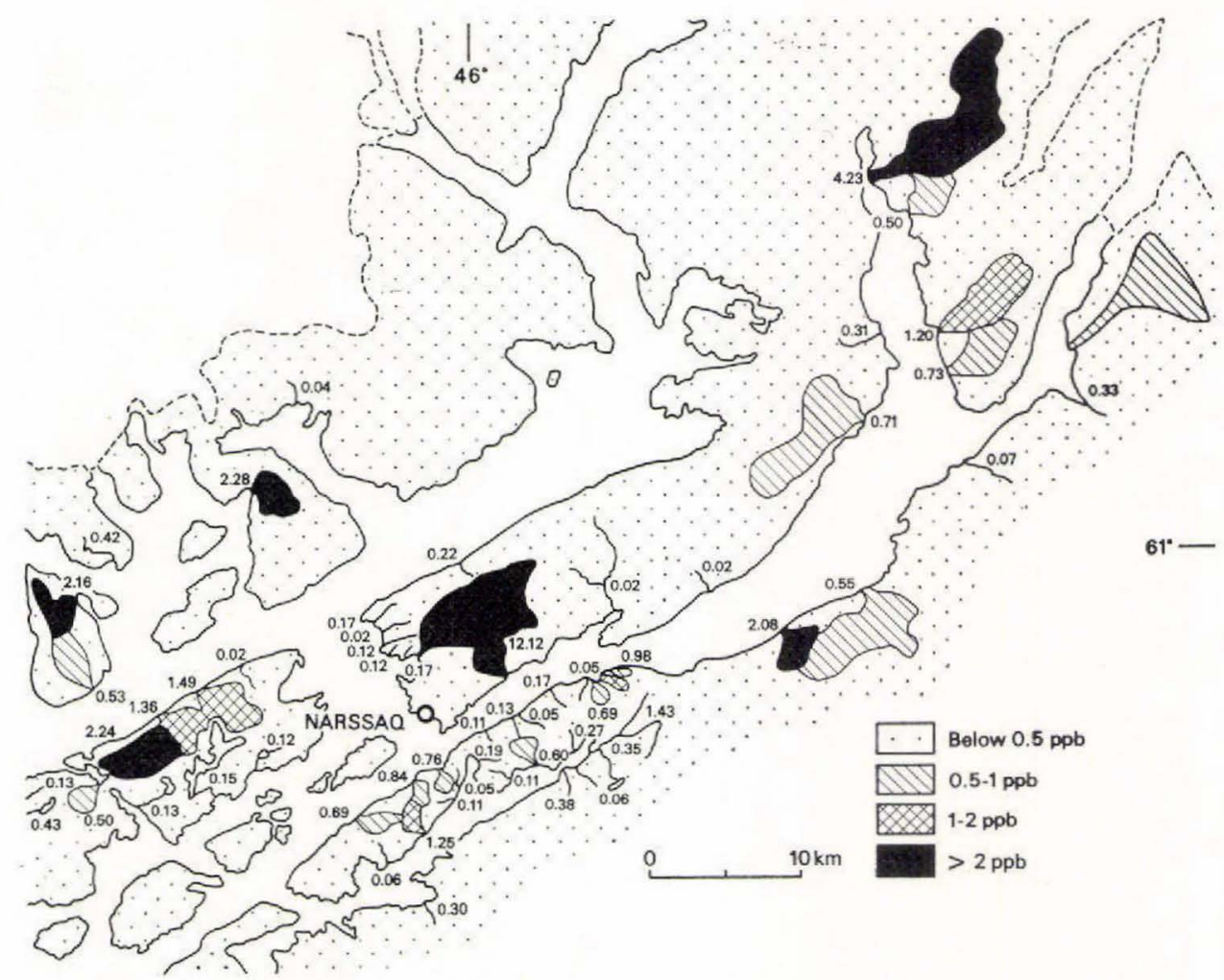

Fig. 18. Uranium content (ppb) in rivers of the Narssaq area.

and its inflow into Narssaq Elv causes a dilution from $1.7 \mathrm{ppb}$ to $0.6 \mathrm{ppb}$ in uranium content. However, following the junction with Taseq Elv (2.1 ppb) the uranium concentration in Narssaq Elv again increases (1.1 ppb).

\section{Other results}

The results of similar geochemical surveys for a larger area are shown in fig. 18 . A particularly interesting case concerns the river Qôrnup kûa $8 \mathrm{~km}$ north of Narssarssuaq where the uranium content at the mouth is $4.23 \mathrm{ppb}$ compared to $1.1 \mathrm{ppb}$ at the mouth of Narssaq Elv.

\section{References}

Asmund, G. 1974: Hydrogeochemical investigations on river water in West, South and East Greenland. Rapp. Gronlands geol. Unders. 65, 71-73.

Larsen, L. B. 1973: Water balance investigations in the Narssaq River Basin, South Greenland. Unpublished GGU Internal Report.

Sørensen, E. in press: Annual Report 1974, Danish Atomic Energy Commission Research Establishment. Chemistry Department, Ris $\varnothing$. 